\title{
HPV disease transmission protection and control
}

\author{
Neil D. Christensen* \\ The Jake Gittlen Laboratories for Cancer Research, Penn State College of Medicine, 500 University Drive, Hershey, PA 17033, USA. \\ * Corresponding Author: \\ Neil D. Christensen, E-mail: waipu6514@gmail.com
}

\begin{abstract}
Human papillomaviruses (HPVs) represent a large collection of viral types associated with significant clinical disease of cutaneous and mucosal epithelium. HPV-associated cancers are found in anogenital and oral mucosa, and at various cutaneous sites. Papillomaviruses are highly species and tissue restricted, and these viruses display both mucosotropic, cutaneotropic or dual tropism for epithelial tissues. A subset of HPV types, predominantly mucosal, are also oncogenic and cancers with these HPV types account for more than 200,000 deaths world-wide. Host control of HPV infections requires both innate and adaptive immunity, but the viruses have developed strategies to escape immune detection. Viral proteins can disrupt both innate pathogen-sensing pathways and T-cell based recognition and subsequent destruction of infected tissues. Current treatments to manage HPV infections include mostly ablative strategies in which recurrences are common and only active disease is treated. Although much is known about the papillomavirus life cycle, viral protein functions, and immune responsiveness, we still lack knowledge in a number of key areas of PV biology including tissue tropism, site-specific cancer progression, codon usage profiles, and what are the best strategies to mount an effective immune response to the carcinogenic stages of PV disease. In this review, disease transmission, protection and control are discussed together with questions related to areas in PV biology that will continue to provide productive opportunities of discovery and to further our understanding of this diverse set of human viral pathogens.
\end{abstract}

doi: $10.15698 / \operatorname{mic} 2016.09 .530$

Received originally: 27.02 .2016 ;

in revised form: 21.05.2016,

Accepted 30.05.2016,

Published 05.09.2016.

\section{Keywords: HPV, animal}

papillomaviruses, pathogenesis, vaccines, immunotherapy, viral oncogenesis, codon modification.

\section{Abbreviations:}

ECM - extracellular matrix,

HPVs - human papillomaviruses,

hrHPV - high-risk HPV,

HSPGs - heparin-sulfate proteoglycans.

\section{INTRODUCTION}

Papillomaviruses are an ancient group of viruses exquisitely adapted to their hosts in a tissue and species-restricted manner (reviewed in [1,2]). The human papillomaviruses (HPVs) are responsible for significant morbidity and mortality in the form of various epithelial infections and cancers of skin, anogenital and oral sites (reviewed in [3-7]). Classification and evolutionary analyses of sequenced genomes suggest that expansion of new PV types from a primordial type began with the appearance of hair and skin glands in ancestral mammals over 200 million years ago [8]. Today, species-specific PVs can be found in most mammals, birds and in several reptiles such as the chelonians and snakes [9]. In humans, over 150 types have been fully sequenced [10], with another 200 different HPV genotypes partially sequenced and many more likely yet to be discovered [11]. HPV infections are both ubiquitous and common in humans and it is fortunate for us all that most of these infections are benign, clinically asymptomatic and controlled by host adaptive immunity. Currently, approximately 15 dif- ferent HPV types labeled as high-risk HPV (hrHPV) have been clearly associated with epithelial cancers [12]. An additional limited number of types are suspected of having carcinogenic potential $[12,13]$. When viewed collectively, all papillomaviruses share several conserved features including:

a. A small double-stranded DNA genome of around $8 \mathrm{~Kb}$, in which numerous viral RNA species are transcribed from one strand only, many of which are represented as multiple spliced transcripts [10].

b. A region containing early genes (usually represented by 5-6 proteins).

c. A region containing two late genes coding for the capsid proteins.

d. A non-coding region containing regulatory elements and a replication origin.

Current control of HPV infections is focused on preventive strategies via induction of neutralizing antibodies; by various ablative strategies for lesion removal, and attempts 
to activate antigen-specific cell-mediated immunity (reviewed in [14]). Questions arise as to why a limited number of these many HPV types progress to malignancy. A combination of immune escape strategies and oncogenic potential of these select types seems the most likely scenario. Many HPV types produce minimal disease and can be best characterized as commensal flora of the skin and mucosa [15]. Another important issue related to host control of HPV infections is whether the infectious HPV "load" present in almost all members of the population generates a mild immune-tolerized state due to the commonness of these viral infections. An alternative hypothesis is that these viruses are predominantly immune "invisible" due to viral immune escape mechanisms and lack of inflammatory events in situ.

Despite current prophylactic vaccines and other treatment strategies, these viruses continue to be a significant health hazard and also a fascinating group of viruses to whet our appetite for new knowledge on keratinocyte biology, viral oncogenesis, viral tissue restriction and viral evolution. In this review we present an overview of PV biology and propose a series of questions that provide a basis for discussion of some areas of interest that continue to represent important gaps in our knowledge in the HPV research field.

\section{ETIOLOGY, TRANSMISSION AND PROTECTION}

Questions relevant to this section:

1. Have we found "all" the different HPV types? What would be the predicted number based on current data sets and extrapolation, and are new HPV types continuing to evolve?

2. Have we identified all viral proteins/products produced by papillomaviruses during their life cycle? Are there any viral miRNA species yet to be discovered?

3. How do new types appear over evolutionary time?

4. At what age do infants become infected with HPV? Is there in utero transmission?

5. How does the adaptive immune system detect HPV infections in the absence of inflammation?

6. Are there sites of infections in patients that show or develop differential immune privilege that allow for increased localized persistence?

7. What innate immune escape strategies utilized by $P V s$ are yet to be discovered?

8. Will vaccination against a restricted set of HPV types lead to replacement with vaccine-unrelated HPV types? Will vaccines accelerate evolutionary changes in vaccine-matched HPV types or elimination of these types?

TABLE 1. Papillomavirus proteins and functions.

\begin{tabular}{|c|c|c|c|}
\hline Viral protein & Function & Host protein interactions & $\begin{array}{c}\text { References } \\
\text { (mostly reviews) }\end{array}$ \\
\hline E1 & Helicase, interacts with PV E2. & DNA polymerase alpha and RPA. & {$[22]$} \\
\hline E2 & $\begin{array}{l}\text { Transcriptional repressor, transcriptional } \\
\text { enhancer. }\end{array}$ & Brd4, TopBP1. & {$[23,24]$} \\
\hline E4 & $\begin{array}{l}\text { Association with the cellular keratin } \\
\text { network. A likely role in virus release and } \\
\text { transmission. }\end{array}$ & Cellular keratins? & [25] \\
\hline E5 & $\begin{array}{l}\text { Hydrophobic protein that can dimerize } \\
\text { growth-factor receptors, deregulate the } \\
\text { autophagic process, modulate epithelial- } \\
\text { mesenchymal transition and reduce } \\
\text { some host microRNA. }\end{array}$ & $\begin{array}{l}\text { Vacuolar ATPase, PDGF, zinc trans- } \\
\text { porter ZnT1, protocadherin } 1 \text { (PCDH1), } \\
\text { and AHNAK/desmoyokin, YIP1 family } \\
\text { member } 4 \text {, calpactin I. }\end{array}$ & $\begin{array}{l}{[20,26,27]} \\
{[28,29]}\end{array}$ \\
\hline E6 & $\begin{array}{l}\text { Viral oncogene. A negative regulator of } \\
\text { UV-DNA damage repair (betaPVs). }\end{array}$ & $\begin{array}{l}\text { p53 (alphaPVs), E6AP (alphaPVs), his- } \\
\text { tone acetyltransferase p300/CBP (be- } \\
\text { taPVs), MAML1 (betaPVs), and pro- } \\
\text { teins containing PDZ domains. } 153 \\
\text { cellular proteins. }\end{array}$ & {$[30,31,32]$} \\
\hline E7 & Viral oncogene. & pRB, CENP-C. & [33] \\
\hline L1 & Major capsid protein. & HSPG, L332, cyclophylins. & {$[34,35,36]$} \\
\hline $\mathrm{L} 2$ & Minor capsid protein. & PATZ, PLINP, PMSP, dynein. & {$[37,38]$} \\
\hline E8 & $\begin{array}{l}\text { E5-like protein in several animal papillo- } \\
\text { maviruses. Not similar to the E8 protein } \\
\text { fragment of many HPVs. }\end{array}$ & $\begin{array}{l}\text { Zinc transporter ZnT1, protocadherin } 1 \\
\text { (PCDH1), and AHNAK/desmoyokin. }\end{array}$ & [39] \\
\hline 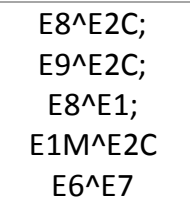 & $\begin{array}{l}\text { Transcriptional repressor. }\left(E 9^{\wedge} E 2 C \text { rep- }\right. \\
\text { resents the equivalent spliced product in } \\
\text { the CRPV genome). }\end{array}$ & NCoR1 and TBLR1. & $\begin{array}{l}{[19,40,41]} \\
{[21]}\end{array}$ \\
\hline
\end{tabular}


HPV types currently number more than 150 genotypes that have been fully sequenced [10]. Papillomavirus researchers have settled on a definition of an HPV type in which a $10 \%$ difference in the base sequence of the L1 gene with all existing HPV types is required to define a new type $[9,16]$. Equivalent classification systems can also be developed from sequence comparisons of the viral E6 oncogene, although, interestingly, these methods do not always yield congruent results [17]. Intriguingly, there appear to be still many new HPV types yet to be detected as demonstrated by recent analyses on tissue samples using deep-sequencing techniques [11]. These new HPV types await further characterization and full sequencing. Classification of papillomaviruses [10] show many different clades or groupings of PVs in which the HPVs are segregated into 3 main groups including Alphapapillomaviruses (mostly mucosotropic), Betapapillomaviruses (mostly cutaneous) and Gammapapillomaviruses (HPVs that include types that can be found in both cutaneous and mucosal sites). When viewed collectively, there remain additional HPV types in other subgroups that are genetically aligned with different animal papillomavirus types.

PV genomes are approximately 8000 bps of doublestranded DNA with ORFs coding for early (E) and late (L) proteins. ORFs have been identified from the coding sequence for E1, E2, E4, E5, E6 and E7 early proteins and L1 and L2 late proteins (Table 1, Figure 1). Confirmation as to whether additional viral proteins are present (or confirmation that we have now identified "all" PV proteins) are challenging experiments to conduct yet several potential reading frames (e.g. E3, E9, E10, L3) remain unstudied and therefore are assumed to be non-functional and/or nonessential. Spliced viral RNA species have been mapped and "new" proteins (e.g. E $8^{\wedge} E 2$ ) have been confirmed by studies in an animal papillomavirus model [18] which is amenable to mutational studies. This new protein was later confirmed to be functional in most HPV types [19]. Given the smallness of the E5 ORF and the redundant functional activities of hydrophobic E5-like proteins [20] we should be encouraged to continue more systematic analysis of other small uncharacterized ORFs and understudied spliced proteins (e.g. E6^E7 [21]) in PV genomes. It is well-recognized in other virus systems that there are many viral proteins that operate as host restriction factors and/or immune function modulators that can be confirmed only by studies using in vivo models.

HPV infections are believed to occur following wounding of epithelium and subsequent infectious virion access to basal epithelial cells and basement membrane components of the epithelium (reviewed in [1]). Enhanced infection following wounding has been confirmed experimentally in preclinical models $[42,43]$. Current diagrams often depict virions entering a breach in the epithelium whereby free virions reach the basal cells and initiate infections. PVassociated lesions are then maintained via persistence of viral-infected basal cells and the lesions increase in mass via replication of infected cells coupled with epithelial differentiation. Vertical maturation of infected keratinocytes completes the virus life cycle culminating in virion assem-

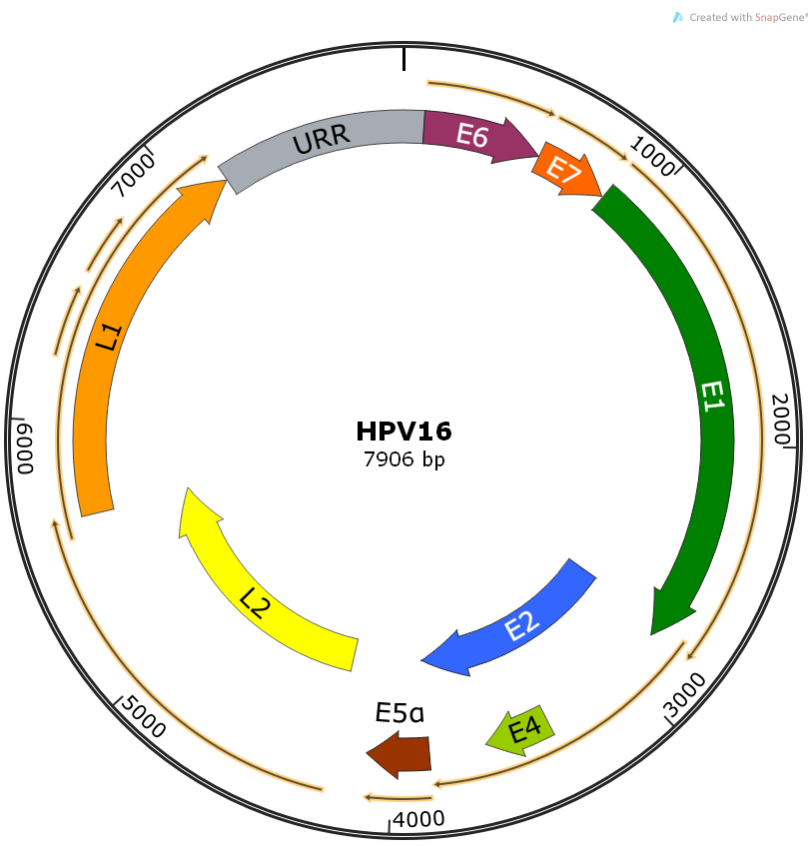

FIGURE 1: HPV16 genome showing viral open reading frames coding for known viral proteins. The Upstream Regulatory Region (URR) is shown in grey. Map constructed using SnapGene software.

bly in the upper layers of the wart. Natural transmission of cutaneous infections likely involves physical contact of the upper keratinized wart with normal skin generating microabrasions allowing virus-containing squames to be shed into the wounded site. Environmental contact between virus-laden shed squames and skin surface wounds are also a likely transmission mechanism. Virion release from the squames may include a combination of keratin filament disassembly events involving viral E4 proteins [25], and host/microbial proteases [44] with subsequent release of the cell-free virions into the wounded site. Mucosal infections are also believed to occur following mechanical wounding during sexual intercourse for vaginal and anal infections.

A question arises as to whether virions can access basal cells via a retro-transport mechanism in areas of epithelial "conflict" at what are known as transition zones located in the cervix and anal canal [45]. Cell culture experiments have demonstrated that virions can bind to cellular filopodia and subsequently be retro-transported significant distances [46] suggesting possible cell-to-cell or cell-to-ECM (extracellular matrix) transfer [34,47] that would bypass the need for direct wounding. Other viruses use a similar strategy of cell-cell transfer and epithelial basement membrane interactions (reviewed in [44]). The transition zone sites [48] are particularly vulnerable to persistent HPV infections that can lead to malignant progression $[45,49]$. A mechanism to describe the selectivity and exclusivity of entry of HPV virions into these unique sites is not easy to reconcile with the general concept of transmission via sitespecific mechanical damage during sexual intercourse. 


\section{Natural protection and control of HPV infections}

Papillomaviruses have developed a variety of strategies to escape host innate and adaptive immunity (reviewed in $[50,51])$. A central tenet for the failure of immune control and detection is the lack of inflammatory events during the various stages of infection. PV infections are confined to epithelial tissues and are highly localized. Several viral proteins are involved in immune escape (Table 1), including: (i) E5, which can down-regulate MHC Class I and other key molecules in the antigen-presentation pathways [52,53]; (ii) E6 and E7, which can suppress host interferon pathways [54-56], activate the DNA-damage pathways [57-59], and induce immune suppression via activation of suppressive cytokines and Tregs [60,61].

Clear evidence for immune control stems from studies on preclinical models [62] and immunosuppressed patients [63-65]. In the preclinical cottontail rabbit PV (CRPV) model, two natural CRPV variants exist in which one variant is poorly immunogenic and produces persistent infections whereas the second variant is immunogenic and easily cleared by host immunity [66]. Several amino acid differences in the E6 protein alone altered the persistor strain to an immunogenic or regressive phenotype [67]. Interestingly, when the rabbits were immunosuppressed prior to infection with the regressive variant then subsequently released from immunosuppression, persistent lesions were observed in some (but not all) animals [68]. These preclinical results support similar observations in immunosuppressed patients where persistent HPV infections are prevalent and can expand to clinical disease during immunosuppression [63]. The implications of these studies are that HPV infections may develop into persistent infections following immune depression arising via temporary environmental stresses. Thus, under normal immunocompetent conditions these infections would have been cleared effectively.

\section{Host restriction factors}

The exquisite tissue restriction of some HPVs has attracted recent interest in the "new" fields of viral-host interactions in which various host restriction factors influence virus life cycles [69]. Some recent observations in HPV in vitro models indicate roles for APOBEC3 family members [70,71], DNA-damage repair (DDR) pathways [57-59], IFN-kappa $[72,73]$, IFI16 [74], TLR9 $[75,76]$ and IL1 $\beta[77,78]$ as host restriction factors or pathways that the virus must overcome. Recent studies on the DNA sensor, IFI16, suggested that the proposed editing of HPV in cervical cancer may be linked to HPV-mediated induction of a human APOBEC3dependent intrinsic host defense mechanism [74]. DDR pathway activation and suppression occurs in HPV replication and carcinogenesis mediated by viral E1 and E2 (repression) and viral E6 and E7 (activation) respectively [59].

New observations on the role of HPV in autophagy also demonstrate host-mediated control pathways disrupted by HPV [79-81]. Finally, there are potential impacts on HPV infection via host microRNA $[82,83]$. Recent studies have begun to search for various miRNA species as markers for HPV-associated cervical and oral cancers and precancers (reviewed in $[84,85])$. Collectively, these areas of research will continue to provide a fruitful avenue of new observations in improving our understanding of host control of HPV infection and carcinogenesis.

\section{Innate and adaptive immune modulators}

Potential innate and adaptive immune control of PV infections must be thwarted by these viruses in order to complete their life cycle. At the same time, the virus must use many host factors and the host replication machinery for completion of their life cycle. Studies show that central adaptive immune control of HPV infections is by type-1 interferon (IFN) and tumor necrosis factor (TNF)- $\alpha$ cytokine-producing $T$ cells [86]. Down-regulation of interferon pathways is a common virus escape mechanism, and HPVs can accomplish innate immune evasion by augmenting the expression of interferon-related developmental regulator 1 (IFRD1) in an EGFR-dependent manner [87]. In addition, the E7 protein of hrHPV has been shown to bind HDAC1 and prevent acetylation of histones, thereby suppressing signaling from the innate immune sensor, TLR9 [75]. Codon usage has also been hypothesized to alter immune detection and responsiveness to different HPV classes [88]. A better understanding of these various immune escape strategies will be needed to improve immunotherapeutic approaches to HPV management.

\section{PATHOLOGY/SYMPTOMATOLOGY}

Questions relevant to this section:

1. Why do infections with some HPV types manifest only as asymptomatic disease whereas others show active clinical disease?

2. Why do infections by different HPV types progress to cancer whereas others do not?

3. Do HPV16-associated cancers at different anatomical locations have a similar pathology, etiology, and progression rate?

4. Are HPV-associated cancers less immunogenic (or have differences in immune escape mechanisms) than precancerous or primary benign HPV infections of the same HPV type?

5. Does the detection of HPV viral DNA correlate $100 \%$ with active clinical disease?

HPV infections present as epithelial lesions that are localized to cutaneous or mucosal sites. All cutaneous tissues are susceptible to HPV infections although mucosal infections are mostly confined to the anogenital and oral cavities as well as laryngeal epithelium. Other less common mucosal sites include bladder, conjunctiva and lung epithelium. The infections range from asymptomatic infections (particularly from the beta- gammapapillomaviruses) to small epithelial lesions to very large cutaneous lesions to large cancerous lesions. In general, most infections are small in size, and present with minimal evidence of infection (no fever, rash, itchiness or any other signs of discomfort). 
Many HPV infections are confirmed by sensitive DNA detection methods rather than via histological or in situ analyses. Those HPV types that produce asymptomatic disease are challenging to locate in situ. That these asymptomatic infections are true infections that complete the virus life cycle and release infectious virions is absolutely confirmed by the existence and persistence of these many HPV types in patient populations.

One HPV type (HPV16) stands out as highly associated with cancers at several different anatomical locations (cervix, penis, anus, oropharynx, and other rare sites such as the esophagus [89] and bladder [90,91]). These lesions have been examined extensively for various diagnostic markers and yet the reasons for differential progression rates and susceptibility of the various sites remain unclear. We also do not yet know whether the innate and adaptive immune systems respond differently to HPV infections at these different anatomical locations. Another unknown is the potential differential immune response to oncogenic HPV infections at the early benign/precancerous stage versus the later carcinomatous stage. There may be enhanced immune escape mechanisms in play in the latter cases that allow a site-specific cancer to eventuate. Also complicating the issue is that there are now a number of different HPV16 subtypes and mutants with differing levels of infection and progression rates in different patient populations [92].

The primary oncogenic potential of HPV types resides in 3 major viral proteins, E5, E6 and E7 [20,93-95]. For hrHPV types in the alphapapillomavirus group, extensive in vitro studies and transgenic animal models have confirmed the oncogenic potential of E6 and E7 proteins [96-101]. Oncogenic activities of the E6 and E7 proteins includes p53 sequestration, pRB binding, interference with DNA damage response pathways, disruption of cell cycle and cell division pathways, and immune evasion (reviewed in [5,51,102]). An oncogenic role for some betapapillomaviruses such as HPV5 and HPV8 includes important co-factors such as UVdamage and include p53 modulation [65,103]. Untreated HPV-associated cancers can progress to malignant cancers that are locally invasive, difficult to treat, and often lead to death of the host. New pathways for transformation are continuing to be identified (e.g. role of autophagy [104]). There is a generalized assumption that malignancies in different anatomical locations initiated by the same HPV type are similar mechanistically. As mentioned previously, we are likely to find both unifying and unique molecular and cellular events when studying HPV16 (and their variants) infections of the cervix, vagina, penis, anus and oral cavity.

HPV types that infect skin show different histopathology when compared with HPV types that infect the mucosa. Notably, differences in the impact of the viral E4 protein expression lead to phenotypic uniqueness of infections by alpha- versus betapapillomaviruses [105]. The high production of the E4 protein in the lesions can be used as a diagnostic marker for various HPV diseases $[106,107]$. New biomarkers are continuing to be discovered and continue to be needed to assist clinical diagnoses, assess treatment outcomes, and to inform physicians as to the appropriate management and treatment of HPV disease.

\section{EPIDEMIOLOGY, INCIDENCE AND PREVALENCE}

Questions relevant to this section:

1. Have we discovered all the risk-factors associated with HPV progression and cancers?

2. What viral and host factors (gender, race, age and anatomical site) are associated with a potential differential susceptibility to HPV infections.

3. Given the commensal nature of some skin and mucosotropic HPV and their prevalence, do these commensal infections provide a potential localized immune tolerance for subsequent infection by the more pathogenic HPVs thereby reducing the initial host immune response to these latter types?

4. Is there competition or synergistic interactions between different HPV types during a co-infection?

5. Do asymptomatic HPV infections trigger protective homeostatic host immunity to these and other common skin microbes? Do other microbes at skin and mucosal sites provide immune "cover" for many asymptomatic HPV infections?

6. Is there a correlation between codon usage profiles and tissue tropism for HPV types?

HPVs are one of the most ubiquitous viral infections with over 300 viral types that infect most cutaneous and many mucosal tissues. Most types are associated with minimal disease and can be described as part of the commensal fauna of these tissues. Numerous epidemiological and molecular studies on cervical cancer demonstrate that hrHPV are associated with up to $99 \%$ with cervical cancers $[3,14]$ This near $100 \%$ association between an infectious agent and a particular cancer is unique to all infectious causes of cancer [108]. Nevertheless, HPVs are considered a necessary but not sufficient cause of HPV-associated cancers [4,109-111] and a number of co-factors and risk-factors have been documented [112]. These co-factors are represented by (i) coincident infectious agents such as EBV, HSV2, HIV and Chlamydia [111,113-117]; (ii) environmental factors (various chemical agents, UV light, immune suppression, stress); (iii) behavioral factors (sexual partners, parity and smoking) and (iv) genetic and epigenetic factors (various polymorphisms in HLA molecules, p53 and GST $[118,119]$, the genetic predisposition known as epidermodysplasia verruciformis, and methylation status of the viral genome) (reviewed in $[1,120,121])$. Several studies have indicated that cervical cancer development and progression may be closely associated with a dual-infection with HPV and EBV $[4,115]$. Infiltrating EBV-infected lymphocytes have been detected in cervical lesions containing episomal hrHPV [115]. The impact of co-incident chronic inflammation and immune modulation via these infectious cofactors has not been studied mechanistically in preclinical models and warrants further study.

HPV of the betapapillomavirus group such as HPV5 and HPV8 are associated with rare incidences of skin cancers, 
and these and other members of this family are considered to also play a role in non-melanoma skin cancers $[30,109$, 122]. The oncogenic potential of members of the betapapillomaviruses are hypothesized to require co-factors including UV light and p53 polymorphisms [123]. The roles of the viral oncogenes in these instances include activation of telomerase and extension of cell life span via E6 [124], and a potential cancer correlation with E6 and polymorphisms in p53 $[103,123]$.

\section{Tissue tropism, latency and viral reservoirs}

There is an exquisite interplay between HPV persistence, tissue tropism and the host innate and adaptive immune response. The keratinocyte is the exclusive host cell of HPVs, and has significant potential to mount both anti-viral responses to PV infections as well as activate adaptive immunity. The tissue tropism introduces the concept of micro-environments in which the host keratinocytes and local immune monitoring are not necessarily identical at different anatomical sites. Possible differences in immune monitoring as well as differences in the natural microbiome in oral and anogenital mucosa also provide mechanistic explanations for HPV tissue tropism $[45,49]$. Epithelial stem cells have attracted interest as a primary source of susceptible cells for initial infection $[45,48]$. The epithelial transition zone may also act as a stem cell niche and thus represents a key location for cellular transformation by accumulated genetic mutations or viral transformation resulting in tumor formation [48]. Several proteins that are induced during wounding are expressed specifically within transition zones, and/or on epithelial stem cells, and may correlate or contribute to HPV-associated transformation [125127].

The exquisite and regional tissue restriction of some HPV types is well-illustrated by such examples as the association of HPV7 with meat-handlers [128]. HPV7 appears to be sufficiently common, but the clinical disease of hand warts appears to be correlated with the unique occupational damage to the hands of these workers rather than via person-to-person transmission of HPV7 [129]. Other skin-tropic HPV types are more common on feet and hands (HPV1/2/4/60/63). Clearly, some HPV types can discriminate at the level of regional tissue sites that the investigator would predict to be tissue-site equivalent. Cellular and molecular differences in keratinocytes are a plausible explanation for these regional specificities, as is the potential differences in the local microbiome and differential immune responsiveness in situ. This phenomenon represents another fruitful area of research for the papillomavirus community. Note too that some HPV types show little tissue restriction and can be found at both mucosal and cutaneous sites (e.g. members of the beta- and gammapapillomaviruses [130]).

The concept of viral latency in papillomaviruses has also raised significant interest in the research community $[15,131]$. Strong circumstantial evidence exists with patients that undergo immunosuppression either by infection (e.g. HIV) or for organ transplantation. Again, the existence of viral DNA and RNA at low levels in clinically normal tis- sues following immune clearance is confirmed in preclinical models [132]. Additional studies to determine the viral mRNA profile would improve our understanding of HPV latency and help determine whether the viral program is reduced in content via immune (and/or innate immune) monitoring or whether distinct components of the viral life cycle are silenced in keeping with other viruses known to have classical latent phenotypes (such as herpesviruses).

The concept of viral reservoirs for secondary infections has attracted limited coverage in the literature [133]. The consensus view is that viral reservoirs include multiple localized infections that may be either clinically active or asymptomatic but which continue to shed infectious virions leading to self-inoculation. Such scenarios may provide a source of virus that can set up secondary infections at transition zones, or sites that are known to progress to malignancies. Recently, non-genital sources of virus present under fingernails has been recorded that could potentially provide an alternate reservoir for future infection although the investigators concluded that this method of transmission is unlikely [134].

Codon usage profiles of papillomavirus proteins show striking differences between the papillomavirus groups [88], between viral proteins $[135,136]$ and disease phenotypes [88]. These studies highlight another intriguing mechanism by which papillomavirus tissue tropism could be influenced, and such concepts can be directly assessed using preclinical papillomavirus models and mutational analyses [137].

Tropism and tissue site selectivity; lessons learned from a mouse PV (MmuPV-1) model.

A new mouse PV model has recently been described that infects cutaneous [138] and mucosal tissues [139]. Although this virus type is clearly genetically dissimilar to the more well-studied alphapapillomaviruses, the tissue restriction of HPV for human tissues prevents mechanistic study of these viruses in vivo and thus preclinical models provide insights into the tissue selectivity of papillomaviruses. We have observed that when the oral cavities of mice are secondarily exposed to MmuPV-1 infectious virions without experimental wounding, select sites in the oral cavity (circumvallate papilla, base of tongue) become preferentially infected despite the observation that most oral mucosa is susceptible to this virus (Figure 2). These studies mimic to some extent, the pre-selection of oral HPVassociated cancers that are confined to the base of tongue, tonsil and oropharynx [5]. We do not yet understand why certain sites in the oral cavity are more vulnerable to HPV malignancies than other sites. Some new observations regarding stem cells in skin hair follicles, cervix and anal epithelial transition zones and tonsillar crypts are suggestive of such cells being prime targets for HPV infection, and sites that preferentially progress towards malignancy $[45,49]$. 


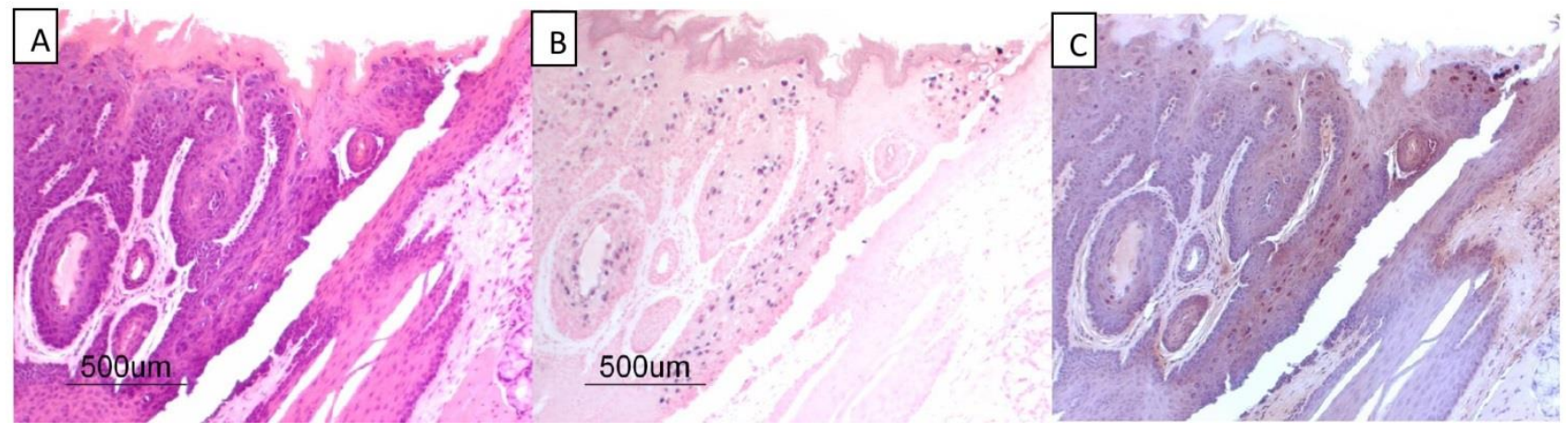

FIGURE 2: MmuPV1 secondary infections of the mouse oral cavity. (A) (H\&E), (B) (in situ hybridization using MmuPV1 DNA probe) and (C) (immunohistochemical staining using a monoclonal antibody to MmuPV-1 L1 protein) detecting an infection localized to the base of the tongue at the circumvallate papilla. (A), (B) and (C) are successive $4 \mu \mathrm{m}$ sections from formalin-fixed paraffin-embedded tissues from athymic mice. One of several examples of MmuPV-1 infection of the circumvallate papilla of the mouse tongue.

\section{TREATMENT AND CURABILITY}

Questions relevant to this section:

1. Why do some patients clear their HPV infections and others do not? Are there genetic, epigenetic and/or environmental components to these different outcomes?

2. Why do many patients clear infections against some HPV types but not others?

3. Do pre-existing co-infections with other infectious agents increase or decrease susceptibility to and persistence of HPV infection?

4. Does immune clearance of HPV infections lead to sterilization of the infection or immune monitoring of a subclinical persistent infection?

5. Why are there so many treatment failures when clinical "cures" appear to have been achieved with various different strategies?

6. Can we develop successful T-cell based immunity to existing HPV disease that can control/clear persistent disease and cancer? Are there additional neo-antigens (in cells with integrated viral DNA) such as host-viral fusion proteins that could serve as potential CD8 T-cell epitopes?

Asymptomatic HPV disease remains untreated as a default. Active clinical disease is diagnosed by both sensitive viral DNA detection methods, and histology or cytology. Monitoring programs (e.g. PAP test) are used to determine the timing and severity of intervention. The PAP smear test examines cells collected by lavage from vaginal sites and cells are examined for histological abnormalities, for viral DNA or for other diagnostic indicators such as increased p16INK4a immunostaining, acid phosphatase positivity, p53, p63, various host microRNA and other additional novel markers [82,85,118,121,126,140-146]. Biopsy material is examined for histological markers and graded using a CIN classification (stages I to IV) or via the Bethesda system for high or low grade dysplasia. Ablative or topical treatments are mostly on an ad hoc basis of treatment of visible lesions seen by colposcopy or acid-white staining.

\section{Therapeutic interventions}

Three prophylactic vaccines are currently approved for control of several high-risk HPV types, and two low-risk types commonly found in genital warts. These include Gardasil (HPV6, 11, 16 and 18), Cervarix (HPV16, 18) and Gardasil9 (HPV6, 11, 16, 18, 31, 35, 45, 52, 58) [147-149]. The vaccines use virus-like particles for the designated HPV types and trigger high titers of type-specific neutralizing antibodies and excellent protection against vaccine-related HPV types [150-152]. Some limited cross-protection against vaccine-related types has been observed in clinical trials [153]. Second-generation vaccines have increased the number of HPV types in the vaccine (e.g. Gardasil9) and are now considering L2-based vaccines that are more broadly cross-protective [154,155].

Therapeutic vaccines based on T-cell responses to virus-infected tissues have been extensively tested in preclinical models, but have enjoyed much less success in clinical trials. Nevertheless, there have been recent encouraging results using long peptide vaccines from HPV16 E6 and E7 for therapeutic T-cell based regression of vaginal intraepithelial infections $[156,157]$. Adoptive transfer of HPV16-reactive T-cells also shows promise against cervical cancer in an initial clinical trial [158]. As we go forward with new and improved immunotherapeutic approaches to manage HPV-associated cancers, there are several challenges to our knowledge base that require further studies. Some examples follow:

a. We need to better understand the various immune suppressive events that occur in situ in HPV-associated cancers that are highly localized [159].

b. We need to design improved strategies to overcome localized T-cell exhaustion and other functional deficiencies that are increasingly being defined in other chronic viral infections [160].

c. We need to better understand and then counteract HPV-induced innate and adaptive immune escape mechanisms to improve T-cell recognition and elimination of HPV infected cells.

d. We need to improve our understanding of T-cell homing to non-immunological tissues (vaginal, anal and 
oral mucosal epithelium) in order to improve the frequency and effector functions of CD8 T-cells [161].

e. We need to improve therapeutic activation of HPVspecific T-cells and assess other potential non-HPV epitopes arising from mutations in cervical cancer to better design vaccines that develop long-lasting immunity $[162,163]$.

Finally, there may be productive opportunities to explore possible sources of neo-antigens in HPV-containing cancer cells that are represented as novel mutations in host cell proteins that provide new CD4 and CD8 epitopes [164-166]. Another possible source of neo-antigens may arise in cancer cells with integrated viral genomes that could express hybrid host/viral fusion proteins. Additional sources of neo-antigens may arise from altered expression of viral proteins through the process of defective ribosomal products (DRiPs) [167-169].

\section{MOLECULAR MECHANISMS OF INFECTION}

Questions relevant to this section:

1. Is wounding essential for successful infection of tissues by infectious virions?

2. Can HPV infections be established from virions that enter sites of epithelial "conflict" as found in transition zones, hair follicles and tonsillar crypts, without the need for environmental wounding?

3. Do all HPV types use the same molecular entry pathway?

4. Do different HPV types interact with different host factors during disease persistence and progression?

5. Is the mechanism of virion entry different for cutaneous versus mucosal epithelium?

6. What are the molecular, genetic and immunological criteria that define tissue-tropism of PVs?

Papillomaviruses are predominantly epitheliotropic. Only a small number of PV types confined to the deltapapillomavirus group induce fibropapillomas in which both epithelial and fibroblast cells are infected [10]. Current dogma proposes that virions enter sites of epithelial damage from wounding. Such wounds expose the basal cells and the basement membrane of the epithelium to virions and the subsequent wound-healing environment is believed to be essential for the establishment and maintenance of PV infections. Wounding may be achieved via mechanical, chemical or biological means. Mechanical damage to skin can occur via cuts, abrasions and UV damage; via intercourse for vaginal and anal mucosa and via eating, smoking and oral cleansing for oral mucosa. Chemical damage can occur via contraceptives, suppositives, oral and vaginal lavage solutions and oxidative damaging agents. Biological damage can occur via co-incident microbial agents such as bacteria, protozoans and fungi that can erode tissues and the basement membrane leading to remodeling and repair of the epithelium [44]. Once basal cells are infected, PV genomes proceed through 3 stages of replication that can be summarized as (i) initial amplification within basal keratinocytes,(ii) followed next by a maintenance phase as the infection becomes established, then (iii) a vegetative stage where viral genomes are amplified to high copy and packaged into virions [58].

\section{In vitro models of entry}

Molecular events of entry have been studied extensively in cell culture systems (reviewed in [36,170-172]). Both native virions from natural infections, xenografts and organotypic cultures as well as synthetic particles prepared in 293TT cells [173] have been used for studies on entry kinetics and receptor analyses [174]. A general consensus of these studies describes a key role for heparin-sulfate proteoglycans (HSPGs) as a primary binding receptor both in vitro [175] and in a pseudovirus infection model of cervicovaginal tissues in mice [43]. Variation in responses is seen when using different viral and pseudoviral systems, different cell lines and different methods for preparing reagents and between different viral types [170].

A series of different host proteins are involved in the various early stages of binding and entry. These include surface heparin-sulfate proteoglycans (e.g. syndecans) $[35,176]$, extracellular matrix (ECM) proteins (e.g. Laminin 332) [34], anexin A2 [177], cyclophilins [178] and tetraspanins [179]. Again, a general consensus model supports the hypothesis that virion binding to HSPGs and ECM components leads to structural changes to the capsid surface allowing exposure of a region of the minor capsid protein to furinase cleavage [180] and subsequent transfer to a secondary receptor for receptor-mediated uptake [181]. Various studies have demonstrated both support and contradiction to several of these proposed steps suggesting that there may be different uptake and entry pathways for the different HPV types rather than a unifying single molecular entry pathway $[170,182,183]$.

\section{In vivo models of entry}

Several animal preclinical models have been used to assess some features of viral entry in situ onto skin and mucosal sites. These studies include mouse cervicovaginal [43] and rabbit skin infection models [184]. These studies provide evidence for a role for HSPGs, for virion targeting to the $\mathrm{ECM}$, and for pre-wounding prior to infection $[42,43]$. The studies also clearly indicate that the PV capsid proteins do not account for tissue and species tropism at the level of viral entry into the epithelial cells. Thus, HPV capsids can efficiently deliver papillomavirus genomes into rabbit skin [184] and plasmid genomes into mouse skin and mucosa [43].

\section{CONCLUSIONS}

Do we have sufficient knowledge about the complex interplay between immune mechanisms of escape, viral carcinogenesis, host innate sensors, transcriptional regulation and codon usage profiles to determine the species and tissue tropism of papillomaviruses?

In summing up, the PV research community has built an impressive body of knowledge on the biological, clinical and pathological activities of papillomaviruses. Significant 
challenges remain in the arena of improved treatments for persistent and latent HPV infections and associated cancers. Preclinical PV models will continue to provide opportunities for more mechanistic studies where the virus and host can be manipulated both genetically and pharmacologically to tease apart contributions of the various components of the virus life cycle. Already, these viruses have enriched our knowledge of viral evolution, tumor suppressor function, host restriction factors, innate immunity, codon usage profiles, viral vaccines, immunotherapy, DNA damage response mechanisms, keratinocyte biology and viral tissue tropism. Future studies will allow us to assess the impact of the current prophylactic vaccines on a select set of HPV types and the selection pressures these vaccines impose on viral evolution. Papillomaviruses have provided a resource for a variety of expertise spanning the fields of virology, immunology, pathology, gynecology, evolutionary biology, vaccine manufacture, carcinogenesis and molecular virology. Questions remaining will continue to challenge future researchers as we continue to study these fascinating viruses.

\section{ACKNOWLEDGMENTS}

This work was funded in part from NIH CA047662 from the $\mathrm{NCl}$. I would like to acknowledge Nancy Cladel and Lynn Budgeon for help with comments and images. The opinions expressed here are founded from many conversations with my colleagues in the papillomavirus research community from which I have enjoyed numerous productive collaborations and interactions. It was not possible to acknowledge their entire collective works in the bibliography and I extend apologies to investigators whose important works were not cited in this review.

\section{CONFLICT OF INTEREST}

I declare no conflict of interest in the preparation of this work.

\section{COPYRIGHT}

(C) 2016 Christensen. This is an open-access article released under the terms of the Creative Commons Attribution (CC BY) license, which allows the unrestricted use, distribution, and reproduction in any medium, provided the original author and source are acknowledged.

Please cite this article as: Neil D. Christensen (2016). HPV disease transmission protection and control. Microbial Cell 3(9): 476-490.

\section{REFERENCES}

1. Doorbar J, Quint W, Banks L, Bravo IG, Stoler M, Broker TR, Stanley MA (2012). The biology and life-cycle of human papillomaviruses. Vaccine 20;30 Suppl 5:F55-F70.

2. Egawa N, Egawa K, Griffin H, Doorbar J (2015). Human Papillomaviruses; Epithelial Tropisms, and the Development of Neoplasia. Viruses 7(7):3863-90.

3. zur Hausen $\mathrm{H}$ (2009). Papillomaviruses in the causation of human cancers - a brief historical account. Virology 384(2):260-5.

4. Galloway DA, Laimins LA (2015). Human papillomaviruses: shared and distinct pathways for pathogenesis. Curr Opin Virol 14:87-92.

5. Doorbar J, Egawa N, Griffin H, Kranjec C, Murakami I (2015). Human papillomavirus molecular biology and disease association. Rev Med Virol 25 Suppl 1:2-23.

6. Gillison ML, Chaturvedi AK, Anderson WF, Fakhry C (2015). Epidemiology of Human Papillomavirus-Positive Head and Neck Squamous Cell Carcinoma. J Clin Oncol 33(29):3235-42.

7. Alemany L, Saunier M, Alvarado-Cabrero I, Quiros B, Salmeron J, Shin HR, Pirog EC, Guimera N, Hernandez-Suarez G, Felix A, Clavero O, Lloveras B, Kasamatsu E, Goodman MT, Hernandez BY, Laco J, Tinoco L, Geraets DT, Lynch CF, Mandys V, Poljak VM, Jach R, Verge J, Clavel C, Ndiaye C, Klaustermeier CJ, Cubilla A, Castellsague X, Bravo IG, Pawlita $M$ et al (2015). Human papillomavirus DNA prevalence and type distribution in anal carcinomas worldwide. Int J Cancer 136(1):98-107.

8. Bravo IG, Felez-Sanchez M (2015). Papillomaviruses: Viral evolution, cancer and evolutionary medicine. Evol Med Public Health 2015(1):32-51.

9. Van Doorslaer K, Bernard HU, Chen Z, de Villiers EM, zur Hausen H, Burk RD (2011). Papillomaviruses: evolution, Linnaean taxonomy and current nomenclature. Trends Microbiol 19(2):49-50.
10. Bioinformatics and Computational Biosciences Branch at the NIAID Office of Cyber Infrastructure and Computational Biology (2016). Papillomavirus Episteme. Available: https://pave.niaid.nih.gov/. Accessed 15.06.2016.

11. Bzhalava D, Muhr LS, Lagheden C, Ekstrom J, Forslund O, Dillner J, Hultin E (2014). Deep sequencing extends the diversity of human papillomaviruses in human skin. Sci Rep 4:5807.

12. Munoz N, Bosch FX, de Sanjose S, Herrero R, Castellsague X, Shah KV, Snijders PJ, Meijer CJ (2003). Epidemiologic classification of human papillomavirus types associated with cervical cancer. N Engl J Med 348(6):518-27.

13. Arbyn M, Tommasino M, Depuydt C, Dillner J (2014). Are 20 human papillomavirus types causing cervical cancer? J Pathol 234(4):431-5.

14. Bosch FX, Broker TR, Forman D, Moscicki AB, Gillison ML, Doorbar J, Stern PL, Stanley MA, Arbyn M, Poljak M, Cuzick J, Castle PE, Schiller JT, Markowitz LE, Fisher WA, Canfell K, Denny LA, Franco EL, Steben M, Kane MA, Schiffman M, Meijer CJ, Sankaranarayanan R, Castellsague X, Kim JJ, Brotons M, Alemany L, Albero G, Diaz GM, de Sanjose S (2013). Comprehensive control of human papillomavirus infections and related diseases. Vaccine 31 Suppl 7:H1-31.

15. Broker TR, Jin G, Croom-Rivers A, Bragg SM, Richardson M, Chow LT, Vermund SH, Alvarez RD, Pappas PG, Squires KE, Hoesley CJ (2001). Viral latency--the papillomavirus model. Dev Biol (Basel) 106:443-51.

16. de Villiers EM (2013). Cross-roads in the classification of

17. van Ranst M, Kaplan JB, Burk RD (1992). Phylogenetic classification of human papillomaviruses: correlation with clinical manifestations. J Gen Virol 73 ( Pt 10):2653-60 papillomaviruses. Virology 445(1-2):2-10. 
18. Jeckel S, Loetzsch E, Huber E, Stubenrauch F, Iftner T (2003). Identification of the E9/E2C CDNA and functional characterization of the gene product reveal a new repressor of transcription and replication in cottontail rabbit papillomavirus. J Virol 77(16):8736-44

19. Stubenrauch F, Hummel M, Iftner T, Laimins LA (2000). The E8E2C protein, a negative regulator of viral transcription and replication, is required for extrachromosomal maintenance of human papillomavirus type 31 in keratinocytes. J Virol 74(3):1178-86

20. DiMaio D, Petti LM (2013). The E5 proteins. Virology 445(1-2):99114

21. Ajiro $M$, Zheng $Z M\left(\right.$ 2015). $E 6^{\wedge} E 7$, a novel splice isoform protein of human papillomavirus 16, stabilizes viral E6 and E7 oncoproteins via HSP90 and GRP78. MBio 6(1):e02068-14.

22. Wilson VG, West M, Woytek K, Rangasamy D (2002). Papillomavirus E1 proteins: form, function, and features. Virus Genes 24(3):275-90.

23. Zheng G, Schweiger MR, Martinez-Noel G, Zheng L, Smith JA, Harper JW, Howley PM (2009). Brd4 regulation of papillomavirus protein E2 stability. J Virol 83(17):8683-92.

24. McBride AA (2013). The papillomavirus E2 proteins. Virology 445(1-2):57-79

25. Doorbar J (2013). The E4 protein; structure, function and patterns of expression. Virology 445(1-2):80-98.

26. Belleudi F, Nanni M, Raffa S, Torrisi MR (2015). HPV16 E5 deregulates the autophagic process in human keratinocytes. Oncotarget 6(11):9370-86.

27. Liu C, Lin J, Li L, Zhang Y, Chen W, Cao Z, Zuo H, Chen C, Kee K (2015). HPV16 early gene E5 specifically reduces miRNA-196a in cervical cancer cells. Sci Rep 5:7653.

28. Schlegel R, Wade-Glass M, Rabson MS, Yang YC (1986). The E5 transforming gene of bovine papillomavirus encodes a small, hydrophobic polypeptide. Science 233(4762):464-7.

29. Krawczyk E, Suprynowicz FA, Hebert JD, Kamonjoh CM, Schlegel R (2011). The human papillomavirus type 16 E5 oncoprotein translocates calpactin I to the perinuclear region. J Virol 85(21):10968 75.

30. Wallace NA, Robinson K, Howie HL, Galloway DA (2015). beta-HPV 5 and 8 E6 disrupt homology dependent double strand break repair by attenuating BRCA1 and BRCA2 expression and foci formation. PLoS Pathog 11(3):e1004687.

31. White EA, Kramer RE, Tan MJ, Hayes SD, Harper JW, Howley PM (2012). Comprehensive analysis of host cellular interactions with human papillomavirus E6 proteins identifies new E6 binding partners and reflects viral diversity. J Virol 86(24):13174-86.

32. Ganti K, Broniarczyk J, Manoubi W, Massimi P, Mittal S, Pim D, Szalmas A, Thatte J, Thomas M, Tomaic V, Banks L (2015). The Human Papillomavirus E6 PDZ Binding Motif: From Life Cycle to Malignancy. Viruses 7(7):3530-51.

33. White EA, Sowa ME, Tan MJ, Jeudy S, Hayes SD, Santha S, Munger K, Harper JW, Howley PM (2012). Systematic identification of interactions between host cell proteins and E7 oncoproteins from diverse human papillomaviruses. Proc Natl Acad Sci USA 109(5):E260E267.

34. Culp TD, Budgeon LR, Marinkovich MP, Meneguzzi G, Christensen ND (2006). Keratinocyte-secreted laminin 5 can function as a transient receptor for human papillomaviruses by binding virions and transferring them to adjacent cells. J Virol 80(18):8940-50.

35. Shafti-Keramat S, Handisurya A, Kriehuber E, Meneguzzi G, Slupetzky K, Kirnbauer R (2003). Different heparan sulfate proteoglycans serve as cellular receptors for human papillomaviruses. J Virol 77(24):13125-35

36. Sapp M, Day PM (2009). Structure, attachment and entry of polyoma- and papillomaviruses. Virology 384(2):400-9.

37. Gornemann J, Hofmann TG, Will H, Muller M (2002). Interaction of human papillomavirus type $16 \mathrm{~L} 2$ with cellular proteins: identification of novel nuclear body-associated proteins. Virology 303(1):69-78.

38. Florin L, Becker KA, Lambert C, Nowak T, Sapp C, Strand D, Streeck $\mathrm{RE}$, Sapp M (2006). Identification of a dynein interacting domain in the papillomavirus minor capsid protein L2. J Virol 80(13):6691-6.

39. Nonnenmacher M, Salmon J, Jacob Y, Orth G, Breitburd F (2006). Cottontail rabbit papillomavirus E8 protein is essential for wart formation and provides new insights into viral pathogenesis. J Virol 80(10):4890-900.

40. Stubenrauch F, Zobel T, Iftner T (2001). The E8 domain confers a novel long-distance transcriptional repression activity on the E8E2C protein of high-risk human papillomavirus type 31. J Virol 75(9):413949.

41. Chiang CM, Broker TR, Chow LT (1991). An E1M--E2C fusion protein encoded by human papillomavirus type 11 is asequencespecific transcription repressor. J Virol 65(6):3317-29.

42. Cladel NM, Hu J, Balogh K, Mejia A, Christensen ND (2008) Wounding prior to challenge substantially improves infectivity of cottontail rabbit papillomavirus and allows for standardization of infection. J Virol Methods 148(1-2):34-9.

43. Roberts JN, Buck CB, Thompson CD, Kines R, Bernardo M, Choyke PL, Lowy DR, Schiller JT (2007). Genital transmission of HPV in a mouse model is potentiated by nonoxynol- 9 and inhibited by carrageenan. Nat Med 13(7):857-61.

44. Singh B, Fleury C, Jalalvand F, Riesbeck K (2012). Human pathogen utilize host extracellular matrix proteins laminin and collagen for adhesion and invasion of the host. FEMS Microbiol Rev 36(6):1122-80.

45. Yang EJ, Quick MC, Hanamornroongruang S, Lai K, Doyle LA McKeon FD, Xian W, Crum CP, Herfs M (2015). Microanatomy of the cervical and anorectal squamocolumnar junctions: a proposed mode for anatomical differences in HPV-related cancer risk. Mod Pathol 28(7):994-1000

46. Schelhaas M, Ewers H, Rajamaki ML, Day PM, Schiller JT, Helenius A (2008). Human papillomavirus type 16 entry: retrograde cell surface transport along actin-rich protrusions. PLoS Pathog 4(9):e1000148.

47. Smith JL, Lidke DS, Ozbun MA (2008). Virus activated filopodia promote human papillomavirus type 31 uptake from the extracellular matrix. Virology 381(1):16-21

48. McNairn AJ, Guasch G (2011). Epithelial transition zones: merging microenvironments, niches, and cellular transformation. Eur J Dermatol 21 Suppl 2:21-8.

49. Mirkovic J, Howitt BE, Roncarati P, Demoulin S, Suarez-Carmona M, Hubert P, McKeon FD, Xian W, Li A, Delvenne P, Crum CP, Herfs M (2015). Carcinogenic HPV infection in the cervical squamo-columnar junction. J Pathol 236(3):265-71.

50. Frazer IH (2009). Interaction of human papillomaviruses with the host immune system: a well evolved relationship. Virology $384(2): 410-4$

51. Stanley MA, Sterling JC (2014). Host responses to infection with human papillomavirus. Curr Probl Dermatol 45:58-74.

52. Ashrafi GH, Tsirimonaki E, Marchetti B, O'Brien PM, Sibbet GJ, Andrew L, Campo MS (2002). Down-regulation of MHC class I by bovine papillomavirus E5 oncoproteins. Oncogene 21(2):248-59. 
53. van Esch EM, Tummers B, Baartmans V, Osse EM, Ter HN, Trietsch MD, Hellebrekers BW, Holleboom CA, Nagel HT, Tan LT, Fleuren GJ, van Poelgeest MI, van der Burg SH, Jordanova ES (2014). Alterations in classical and nonclassical HLA expression in recurrent and progressive HPV-induced usual vulvar intraepithelial neoplasia and implications for immunotherapy. Int J Cancer 135(4):830-42.

54. Um SJ, Rhyu JW, Kim EJ, Jeon KC, Hwang ES, Park JS (2002). Abrogation of IRF-1 response by high-risk HPV E7 protein in vivo. Cancer Lett 179(2):205-12.

55. Barnard P, McMillan NA (1999). The human papillomavirus E7 oncoprotein abrogates signaling mediated by interferon-alpha. Virology 259(2):305-13.

56. Beglin $M$, Melar-New M, Laimins L (2009). Human papillomaviruses and the interferon response. J Interferon Cytokine Res 29(9):629-35.

57. Hong S, Laimins LA (2013). Regulation of the life cycle of HPVs by differentiation and the DNA damage response. Future Microbiol 8(12):1547-57.

58. McKinney CC, Hussmann KL, McBride AA (2015). The Role of the DNA Damage Response throughout the Papillomavirus Life Cycle. Viruses 7(5):2450-69.

59. Wallace NA, Galloway DA (2014). Manipulation of cellular DNA damage repair machinery facilitates propagation of human papillomaviruses. Semin Cancer Biol 26:30-42.

60. van Esch EM, van Poelgeest MI, Trimbos JB, Fleuren GJ, Jordanova ES, van der Burg SH (2015). Intraepithelial macrophage infiltration is related to a high number of regulatory $\mathrm{T}$ cells and promotes a progressive course of HPV-induced vulvar neoplasia. Int J Cancer 136(4):E85-E94.

61. Santegoets SJ, Dijkgraaf EM, Battaglia A, Beckhove P, Britten CM, Gallimore A, Godkin A, Gouttefangeas C, de Gruijl TD, Koenen HJ, Scheffold A, Shevach EM, Staats J, Tasken K, Whiteside TL, Kroep JR, Welters MJ, van der Burg SH (2015). Monitoring regulatory T cells in clinical samples: consensus on an essential marker set and gating strategy for regulatory $T$ cell analysis by flow cytometry. Cancer Immunol Immunother 64(10):1271-86.

62. Handisurya A, Day PM, Thompson CD, Bonelli M, Lowy DR, Schiller JT (2014). Strain-specific properties and $T$ cells regulate the susceptibility to papilloma induction by Mus musculus papillomavirus 1. PLoS Pathog 10(8):e1004314.

63. Reusser NM, Downing C, Guidry J, Tyring SK (2015). HPV Carcinomas in Immunocompromised Patients. J Clin Med 4(2):260-81.

64. Wieland U, Kreuter A, Pfister $H$ (2014). Human papillomavirus and immunosuppression. Curr Probl Dermatol 45:154-65.

65. Shamanin V, zur Hausen $H$, Lavergne $D$, Proby CM, Leigh IM, Neumann C, Hamm H, Goos M, Haustein UF, Jung EG, Plewig G, Wolff $H$, de Villiers EM (1996). Human papillomavirus infections in nonmelanoma skin cancers from renal transplant recipients and nonimmunosuppressed patients. J Natl Cancer Inst 88(12):802-11.

66. Salmon J, Nonnenmacher M, Caze S, Flamant P, Croissant O, Orth $G$, Breitburd F (2000). Variation in the nucleotide sequence of cottontail rabbit papillomavirus $a$ and $b$ subtypes affects wart regression and malignant transformation and level of viral replication in domestic rabbits. J Virol 74(22):10766-77.

67. Hu J, Cladel NM, Pickel MD, Christensen ND (2002). Amino acid residues in the carboxy-terminal region of cottontail rabbit papillomavirus E6 influence spontaneous regression of cutaneous papillomas. J Virol 76(23):11801-8.

68. Hu J, Peng X, Cladel NM, Pickel MD, Christensen ND (2005). Large cutaneous rabbit papillomas that persist during cyclosporin $\mathrm{A}$ treatment can regress spontaneously after cessation of immunosuppression. J Gen Virol 86(Pt 1):55-63.

69. Reinholz M, Kawakami Y, Salzer S, Kreuter A, Dombrowski Y, Koglin S, Kresse S, Ruzicka T, Schauber J (2013). HPV16 activates the AIM2 inflammasome in keratinocytes. Arch Dermatol Res 305(8):723-32.

70. Warren CJ, Xu T, Guo K, Griffin LM, Westrich JA, Lee D, Lambert PF, Santiago ML, Pyeon D (2015). APOBEC3A functions as a restriction factor of human papillomavirus. J Virol 89(1):688-702.

71. Vartanian JP, Guetard D, Henry M, Wain-Hobson S (2008). Evidence for editing of human papillomavirus DNA by APOBEC3 in benign and precancerous lesions. Science 320(5873):230-3.

72. Habiger C, Jager G, Walter M, Iftner T, Stubenrauch F (2015). IFNkappa inhibits HPV31 transcription by inducing Sp100 proteins. J Virol 90(2):694-704.

73. Reiser J, Hurst J, Voges $M$, Krauss $P$, Munch $P$, Iftner $T$, Stubenrauch $F$ (2011). High-risk human papillomaviruses repress constitutive kappa interferon transcription via E6 to prevent pathogen recognition receptor and antiviral-gene expression. J Virol 85(21):11372-80.

74. Lo Cigno, I, De AM, Borgogna C, Albertini S, Landini MM, Peretti A Johnson KE, Chandran B, Landolfo S, Gariglio M (2015). The Nuclear DNA Sensor IFI16 Acts as a Restriction Factor for Human Papillomavirus Replication through Epigenetic Modifications of the Viral Promoters. J Virol 89(15):7506-20.

75. Hasan UA, Bates E, Takeshita F, Biliato A, Accardi R, Bouvard V, Mansour M, Vincent I, Gissmann L, Iftner T, Sideri M, Stubenrauch F, Tommasino $M$ (2007). TLR9 expression and function is abolished by the cervical cancer-associated human papillomavirus type 16 . J Immunol 178(5):3186-97.

76. Hao Y, Yuan JL, Abudula A, Hasimu A, Kadeer N, Guo X (2014). TLR9 expression in uterine cervical lesions of Uyghur women correlate with cervical cancer progression and selective silencing of human papillomavirus 16 E6 and E7 oncoproteins in vitro. Asian Pac J Cancer Prev 15(14):5867-72.

77. Niebler M, Qian X, Hofler D, Kogosov V, Kaewprag J, Kaufmann AM, Ly R, Bohmer G, Zawatzky R, Rosl F, Rincon-Orozco B (2013). Posttranslational control of IL-1beta via the human papillomavirus type 16 E6 oncoprotein: a novel mechanism of innate immune escape mediated by the E3-ubiquitin ligase E6-AP and p53. PLoS Pathog 9(8):e1003536

78. Karim R, Tummers B, Meyers C, Biryukov JL, Alam S, Backendorf C Jha V, Offringa R, van Ommen GJ, Melief CJ, Guardavaccaro D, Boer $J M$, van der Burg SH (2013). Human papillomavirus (HPV) upregulates the cellular deubiquitinase UCHL1 to suppress the keratinocyte's innate immune response. PLoS Pathog 9(5):e1003384.

79. Chen TC, Hung YC, Lin TY, Chang HW, Chiang IP, Chen YY, Chow KC (2011). Human papillomavirus infection and expression of ATPase family AAA domain containing $3 \mathrm{~A}$, a novel anti-autophagy factor, in uterine cervical cancer. Int J Mol Med 28(5):689-96.

80. Griffin LM, Cicchini L, Pyeon D (2013). Human papillomavirus infection is inhibited by host autophagy in primary human keratinocytes. Virology 437(1):12-9.

81. Surviladze Z, Sterk RT, DeHaro SA, Ozbun MA (2013). Cellular entry of human papillomavirus type 16 involves activation of the phosphatidylinositol 3-kinase/Akt/mTOR pathway and inhibition of autophagy. J Virol 87(5):2508-17.

82. Martinez I, Gardiner AS, Board KF, Monzon FA, Edwards RP, Khan SA (2008). Human papillomavirus type 16 reduces the expression of microRNA-218 in cervical carcinoma cells. Oncogene 27(18):2575-82. 
83. Wang X, Tang S, Le SY, Lu R, Rader JS, Meyers C, Zheng ZM (2008). Aberrant expression of oncogenic and tumor-suppressive microRNAs in cervical cancer is required for cancer cell growth. PLoS One 3(7):e2557.

84. Zheng ZM, Wang X (2011). Regulation of cellular miRNA expression by human papillomaviruses. Biochim Biophys Acta 1809(11-12):668 77.

85. Wang X, Wang HK, Li Y, Hafner M, Banerjee NS, Tang S, Briskin D, Meyers C, Chow LT, Xie X, Tuschl T, Zheng ZM (2014). microRNAs are biomarkers of oncogenic human papillomavirus infections. Proc Nat Acad Sci USA 111(11):4262-7.

86. van der Burg SH, Melief CJ (2011). Therapeutic vaccination against human papilloma virus induced malignancies. Curr Opin Immunol 23(2):252-7

87. Tummers B, Goedemans R, Pelascini LP, Jordanova ES, van Esch EM, Meyers C, Melief CJ, Boer JM, van der Burg SH (2015). The interferon-related developmental regulator 1 is used by human papillomavirus to suppress NFkappaB activation. Nat Commun 6:6537.

88. Felez-Sanchez M, Trosemeier JH, Bedhomme S, Gonzalez-Bravo MI, Kamp C, Bravo IG (2015). Cancer, Warts, or Asymptomatic Infections: Clinical Presentation Matches Codon Usage Preferences in Human Papillomaviruses. Genome Biol Evol 7(8):2117-35.

89. Liyanage SS, Segelov E, Garland SM, Tabrizi SN, Seale H, Crowe PJ, Dwyer DE, Barbour A, Newall AT, Malik A, Macintyre CR (2013). Role of human papillomaviruses in esophageal squamous cell carcinoma. Asia Pac J Clin Oncol 9(1):12-28.

90. Husain E, Prowse DM, Ktori E, Shaikh T, Yaqoob M, Junaid I, Baithun S (2009). Human papillomavirus is detected in transitional cell carcinoma arising in renal transplant recipients. Pathology 41(3):245-7.

91. Li N, Yang L, Zhang Y, Zhao P, Zheng T, Dai M (2011). Human papillomavirus infection and bladder cancer risk: a meta-analysis. Infect Dis 204(2):217-23

92. Cullen M, Boland JF, Schiffman M, Zhang X, Wentzensen N, Yang $Q$ Chen Z, Yu K, Mitchell J, Roberson D, Bass S, Burdette L, Machado M, Ravichandran S, Luke B, Machiela MJ, Andersen M, Osentoski M, Laptewicz M, Wacholder S, Feldman A, Raine-Bennett T, Lorey T, Castle PE, Yeager M, Burk RD, Mirabello $L$ (2015). Deep sequencing of HPV16 genomes: A new high-throughput tool for exploring the carcinogenicity and natural history of HPV16 infection. Papillomavirus Res 1:3-11.

93. Munger K, Phelps WC (1993). The human papillomavirus E7 protein as a transforming and transactivating factor. Biochim Biophys Acta $1155(1): 111-23$.

94. Tommasino $\mathrm{M}$, Crawford L (1995). Human papillomavirus E6 and E7: proteins which deregulate the cell cycle. Bioessays17(6):509-18.

95. Huibregtse JM, Beaudenon SL (1996). Mechanism of HPV E6 proteins in cellular transformation. Semin Cancer Biol 7(6):317-26.

96. Pater MM, Hughes GA, Hyslop DE, Nakshatri H, Pater A (1988). Glucocorticoid-dependent oncogenic transformation by type 16 but not type 11 human papilloma virus DNA. Nature 335(6193):832-5.

97. Thierry $F$ (2009). Transcriptional regulation of the papillomavirus oncogenes by cellular and viral transcription factors in cervical carcinoma. Virology 384(2):375-9.

98. Thomas MK, Pitot HC, Liem A, Lambert PF (2011). Dominant role of HPV16 E7 in anal carcinogenesis. Virology 421(2):114-8

99. Hufbauer M, Lazic D, Reinartz M, Akgul B, Pfister $H$, Weissenborn SJ (2011). Skin tumor formation in human papillomavirus 8 transgenic mice is associated with a deregulation of oncogenic miRNAs and their tumor suppressive targets. J Dermatol Sci 64(1):7-15.
100. Frazer IH, Leippe DM, Dunn LA, Liem A, Tindle RW, Fernando GJ, Phelps WC, Lambert PF (1995). Immunological responses in human papillomavirus 16 E6/E7-transgenic mice to E7 protein correlate with the presence of skin disease. Cancer Res 55(12):2635-9.

101. Kondoh G, Li Q, Pan J, Hakura A (1995). Transgenic models for papillomavirus-associated multistep carcinogenesis. Intervirology 38(3-4):181-6.

102. McLaughlin-Drubin ME, Munger K (2009). Oncogenic activities of human papillomaviruses. Virus Res 143(2):195-208.

103. Fei JW, de Villiers EM (2012). Differential regulation of cutaneous oncoprotein HPVE6 by wtp53, mutant p53R248W and DeltaNp63alpha is HPV type dependent. PLoS One 7(4):e35540.

104. Pandey S, Chandravati (2012). Autophagy in cervical cancer: an emerging therapeutic target. Asian Pac J Cancer Prev 13(10):4867-71.

105. Borgogna C, Landini MM, Lanfredini S, Doorbar J, Bouwes Bavinck JN, Quint KD, de Koning MN, Genders RE, Gariglio M (2014). Characterization of skin lesions induced by skin-tropic alpha- and beta-papillomaviruses in a patient with epidermodysplasia verruciformis. Br J Dermatol 171(6):1550-4.

106. van Baars R, Griffin H, Wu Z, Soneji YJ, van de Sandt MM, Arora R, van der Marel J, Ter HB, Jach R, Okon K, Huras H, Jenkins D, Quint WG, Doorbar J (2015). Investigating Diagnostic Problems of CIN1 and CIN2 Associated With High-risk HPV by Combining the Novel Molecular Biomarker PanHPVE4 With P16INK4a. Am J Surg Pathol 39(11):151828

107. Griffin $H$, Soneji $Y$, van $B R$, Arora $R$, Jenkins $D$, van de Sandt $M$ Wu Z, Quint W, Jach R, Okon K, Huras H, Singer A, Doorbar J (2015) Stratification of HPV-induced cervical pathology using the virally encoded molecular marker E4 in combination with p16 or MCM. Mod Pathol 28(7):977-93.

108. zur Hausen $H$, de Villiers EM (2015). Reprint of: cance "causation" by infections--individual contributions and synergistic networks. Semin Oncol 42(2):207-22.

109. Bosch FX, de Sanjose S (2007). The epidemiology of human papillomavirus infection and cervical cancer. Dis Markers 23(4):213-27.

110. Cavalcanti SM, Zardo LG, Passos MR, Oliveira LH (2000). Epidemiological aspects of human papillomavirus infection and cervical cancer in Brazil. J Infect 40(1):80-7.

111. Bellaminutti S, Seraceni S, De SF, Gheit T, Tommasino M, Comar M (2014). HPV and Chlamydia trachomatis co-detection in young asymptomatic women from high incidence area for cervical cancer. J Med Virol 86(11):1920-5

112. Hildesheim A, Herrero R, Castle PE, Wacholder S, Bratti MC Sherman ME, Lorincz AT, Burk RD, Morales J, Rodriguez AC, Helgesen K, Alfaro M, Hutchinson M, Balmaceda I, Greenberg M, Schiffman M (2001). HPV co-factors related to the development of cervical cancer: results from a population-based study in Costa Rica. Br J Cancer 84(9):1219-26.

113. Landers RJ, O'Leary JJ, Crowley M, Healy I, Annis P, Burke L, O'Brien D, Hogan J, Kealy WF, Lewis FA (1993). Epstein-Barr virus in normal, pre-malignant, and malignant lesions of the uterine cervix. $J$ Clin Pathol 46(10):931-5.

114. Marinho-Dias J, Ribeiro J, Monteiro P, Loureiro J, Baldaque I, Medeiros R, Sousa H (2013). Characterization of cytomegalovirus and epstein-barr virus infection in cervical lesions in Portugal. J Med Virol 85(8):1409-13.

115. Aromseree $S$, Pientong $C$, Swangphon $P$, Chaiwongkot $A$ Patarapadungkit N, Kleebkaow $P$, Tungsiriwattana $T$, Kongyingyoes $B$, Vendrig T, Middeldorp JM, Ekalaksananan $T$ (2015). Possible contributing role of Epstein-Barr virus (EBV) as a cofactor in human 
papillomavirus (HPV)-associated cervical carcinogenesis. J Clin Virol 73:70-6.

116. McDougall JK, Nelson JA, Myerson D, Beckmann AM, Galloway DA (1984). HSV, CMV, and HPV in human neoplasia. J Invest Dermatol 83(1 Suppl):72s-6s.

117. Prakash SS, Reeves WC, Sisson GR, Brenes M, Godoy J, Bacchetti S, de Britton RC, Rawls WE (1985). Herpes simplex virus type 2 and human papillomavirus type 16 in cervicitis, dysplasia and invasive cervical carcinoma. Int J Cancer 35(1):51-7.

118. Wang TY, Chen BF, Yang YC, Chen H, Wang Y, Cviko A, Quade BJ, Sun D, Yang A, McKeon FD, Crum CP (2001). Histologic and immunophenotypic classification of cervical carcinomas by expression of the p53 homologue p63: a study of 250 cases. Hum Pathol 32(5):479-86

119. Palma S, Novelli F, Padua L, Venuti A, Prignano G, Mariani L, Cozzi R, Tirindelli D, Testa A (2010). Interaction between glutathione-Stransferase polymorphisms, smoking habit, and HPV infection in cervical cancer risk. J Cancer Res Clin Oncol 136(7):1101-9.

120. White EA, Howley PM (2013). Proteomic approaches to the study of papillomavirus-host interactions. Virology 435(1):57-69.

121. Zheng ZM, Baker CC (2006). Papillomavirus genome structure, expression, and post-transcriptional regulation. Front Biosci 11:2286302.

122. Feltkamp MC, de Koning MN, Bavinck JN, Ter SJ (2008). Betapapillomaviruses: innocent bystanders or causes of skin cancer. J Clin Virol 43(4):353-60.

123. Loeb KR, Asgari MM, Hawes SE, Feng Q, Stern JE, Jiang M, Argenyi ZB, de Villiers EM, Kiviat NB (2012). Analysis of Tp53 codon 72 polymorphisms, Tp53 mutations, and HPV infection in cutaneous squamous cell carcinomas. PLoS One 7(4):e34422.

124. Bedard KM, Underbrink MP, Howie HL, Galloway DA (2008). The E6 oncoproteins from human betapapillomaviruses differentially activate telomerase through an E6AP-dependent mechanism and prolong the lifespan of primary keratinocytes. J Virol 82(8):3894-902.

125. da Silva-Diz V, Sole-Sanchez S, Valdes-Gutierrez A, Urpi M, RibaArtes D, Penin RM, Pascual G, Gonzalez-Suarez E, Casanovas O, Vinals F, Paramio JM, Batlle E, Munoz P (2013). Progeny of Lgr5-expressing hair follicle stem cell contributes to papillomavirus-induced tumor development in epidermis. Oncogene 32(32):3732-43.

126. Martens JE, Arends J, Van der Linden PJ, De Boer BA, Helmerhorst TJ (2004). Cytokeratin 17 and p63 are markers of the HPV target cell, the cervical stem cell. Anticancer Res 24(2B):771-5.

127. Chen Q, Cao HZ, Zheng PS (2014). LGR5 promotes the proliferation and tumor formation of cervical cancer cells through the Wnt/beta-catenin signaling pathway. Oncotarget 5(19):9092-105.

128. Keefe M, al-Ghamdi A, Coggon D, Maitland NJ, Egger P, Keefe CJ, Carey A, Sanders CM (1994). Cutaneous warts in butchers. Br J Dermatol 130(1):9-14.

129. Keefe M, al-Ghamdi A, Coggon D, Maitland NJ, Egger P, Keefe CJ, Carey A, Sanders CM (1994). Butchers' warts: no evidence for person to person transmission of HPV7. Br J Dermatol 130(1):15-7.

130. Bottalico D, Chen Z, Dunne A, Ostoloza J, McKinney S, Sun C, Schlecht NF, Fatahzadeh M, Herrero R, Schiffman M, Burk RD (2011). The oral cavity contains abundant known and novel human papillomaviruses from the Betapapillomavirus and Gammapapillomavirus genera. J Infect Dis 204(5):787-92.

131. Maglennon GA, Doorbar J (2012). The biology of papillomavirus latency. Open Virol J 6:190-7.
132. Maglennon GA, Mclntosh P, Doorbar J (2011). Persistence of viral DNA in the epithelial basal layer suggests a model for papillomavirus latency following immune regression. Virology 414(2):153-63.

133. Koliopoulos G, Valari O, Karakitsos P, Paraskevaidis E (2013). Predictors and clinical implications of HPV reservoire districts for genital tract disease. Curr Pharm Des 19(8):1395-400.

134. Fu TC, Hughes JP, Feng Q, Hulbert A, Hawes SE, Xi LF, Schwartz SM, Stern JE, Koutsky LA, Winer RL (2015). Epidemiology of Human Papillomavirus Detected in the Oral Cavity and Fingernails of MidAdult Women. Sex Transm Dis 42(12):677-85.

135. Zhao KN, Gu W, Fang NX, Saunders NA, Frazer IH (2005). Gene codon composition determines differentiation-dependent expression of a viral capsid gene in keratinocytes in vitro and in vivo. Mol Cell Biol 25(19):8643-55.

136. Cladel NM, Bertotto A, Christensen ND (2010). Human alpha and beta papillomaviruses use different synonymous codon profiles. Virus Genes 40(3):329-40.

137. Cladel NM, Budgeon LR, Hu J, Balogh KK, Christensen ND (2013). Synonymous codon changes in the oncogenes of the cottontail rabbit papillomavirus lead to increased oncogenicity and immunogenicity of the virus. Virology 438(2):70-83.

138. Ingle A, Ghim S, Joh J, Chepkoech I, Bennett JA, Sundberg JP (2011). Novel laboratory mouse papillomavirus (MusPV) infection. Vet Pathol 48(2):500-5.

139. Cladel NM, Budgeon LR, Balogh KK, Cooper TK, Hu J, Christensen ND (2015). Mouse papillomavirus MmuPV1 infects oral mucosa and preferentially targets the base of the tongue. Virology 488:73-80.

140. Selvi K, Badhe BA, Papa D, Ganesh RN (2014). Role of p16, CK17, p63, and human papillomavirus in diagnosis of cervical intraepithelial neoplasia and distinction from its mimics. Int J Surg Pathol 22(3):221 30 .

141. Pinto AP, Degen M, Villa LL, Cibas ES (2012). Immunomarkers in gynecologic cytology: the search for the ideal 'biomolecular Papanicolaou test'. Acta Cytol 56(2):109-21.

142. Srivastava K, Pickard A, McDade S, McCance DJ (2015). p63 drives invasion in keratinocytes expressing HPV16 E6/E7 genes through regulation of Src-FAK signalling. Oncotarget 7.

143. Wang SS, Trunk $M$, Schiffman $M$, Herrero $R$, Sherman ME, Burk RD, Hildesheim A, Bratti MC, Wright T, Rodriguez AC, Chen S, Reichert $A$, von Knebel DC, Ridder R, von Knebel DM (2004). Validation of p16INK4a as a marker of oncogenic human papillomavirus infection in cervical biopsies from a population-based cohort in Costa Rica. Cancer Epidemiol Biomarkers Prev 13(8):1355-60.

144. Zhang J, Wang L, Qiu M, Liu Z, Qian W, Yang Y, Wu S, Feng Y (2013). The protein levels of MCM7 and p63 in evaluating lesion severity of cervical disease. Int J Gynecol Cancer 23(2):318-24.

145. Zielinski GD, Snijders PJ, Rozendaal L, Daalmeijer NF, Risse EK, Voorhorst FJ, Jiwa NM, van der Linden HC, de Schipper FA, Runsink AP, Meijer CJ (2003). The presence of high-risk HPV combined with specific p53 and p16INK4a expression patterns points to high-risk HPV as the main causative agent for adenocarcinoma in situ and adenocarcinoma of the cervix. J Pathol 201(4):535-43.

146. Martin CM, Astbury K, Kehoe L, O'Crowley JB, O'Toole S, O'Leary JJ (2015). The use of MYBL2 as a novel candidate biomarker of cervical cancer. Methods Mol Biol 1249:241-51.

147. Einstein $M H$, Takacs $P$, Chatterjee A, Sperling RS, Chakhtoura N, Blatter MM, Lalezari J, David MP, Lin L, Struyf F, Dubin G (2014). Comparison of long-term immunogenicity and safety of human papillomavirus (HPV)-16/18 ASO4-adjuvanted vaccine and HPV$6 / 11 / 16 / 18$ vaccine in healthy women aged $18-45$ years: end-of-study 
analysis of a Phase III randomized trial. Hum Vaccin Immunother 10(12):3435-45.

148. Vichnin M, Bonanni $P$, Klein NP, Garland SM, Block SL, Kjaer SK, Sings HL, Perez G, Haupt RM, Saah AJ, Lievano F, Velicer C, Drury R, Kuter BJ (2015). An Overview of Quadrivalent Human Papillomavirus Vaccine Safety: 2006 to 2015. Pediatr Infect Dis J 34(9):983-91.

149. Garland SM, Cheung TH, McNeill S, Petersen LK, Romaguera J, Vazquez-Narvaez J, Bautista O, Shields C, Vuocolo S, Luxembourg A (2015). Safety and immunogenicity of a 9-valent HPV vaccine in females 12-26 years of age who previously received the quadrivalent HPV vaccine. Vaccine 33(48):6855-64.

150. Koutsky LA, Ault KA, Wheeler CM, Brown DR, Barr E, Alvarez FB, Chiacchierini LM, Jansen KU (2002). A controlled trial of a human papillomavirus type 16 vaccine. N Engl J Med 347(21):1645-51.

151. Brown DR, Garland SM, Ferris DG, Joura E, Steben M, James M, Radley D, Vuocolo S, Garner El, Haupt RM, Bryan JT (2011). The humoral response to Gardasil over four years as defined by total IgG and competitive Luminex immunoassay. Hum Vaccin 7(2):230-8.

152. Kemp TJ, Garcia-Pineres A, Falk RT, Poncelet S, Dessy F, Giannini SL, Rodriguez AC, Porras C, Herrero R, Hildesheim A, Pinto LA (2008). Evaluation of systemic and mucosal anti-HPV16 and anti-HPV18 antibody responses from vaccinated women. Vaccine 26(29-30):360816.

153. Kemp TJ, Hildesheim A, Safaeian M, Dauner JG, Pan Y, Porras C, Schiller JT, Lowy DR, Herrero R, Pinto LA (2011). HPV16/18 L1 VLP vaccine induces cross-neutralizing antibodies that may mediate crossprotection. Vaccine 29(11):2011-4.

154. Roden RB, Yutzy WH, Fallon R, Inglis S, Lowy DR, Schiller JT (2000) Minor capsid protein of human genital papillomaviruses contains subdominant, cross-neutralizing epitopes. Virology 270(2):254-7.

155. Jagu S, Karanam B, Gambhira R, Chivukula SV, Chaganti RJ, Lowy DR, Schiller JT, Roden RB (2009). Concatenated multitype L2 fusion proteins as candidate prophylactic pan-human papillomavirus vaccines. J Natl Cancer Inst 101(11):782-92.

156. Welters MJ, Kenter GG, de Vos van Steenwijk PJ, Lowik MJ, Berends-van der Meer DM, Essahsah F, Stynenbosch LF, Vloon AP, Ramwadhdoebe TH, Piersma SJ, van der Hulst JM, Valentijn AR, Fathers LM, Drijfhout JW, Franken KL, Oostendorp J, Fleuren GJ, Melief CJ, van der Burg SH (2010). Success or failure of vaccination for HPV16-positive vulvar lesions correlates with kinetics and phenotype of induced T-cell responses. Proc Natl Acad Sci USA 107(26):11895-9.

157. van Poelgeest MI, Welters MJ, van Esch EM, Stynenbosch LF, Kerpershoek G, van Persijn van Meerten EL, van den Hende M, Lowik MJ, Berends-van der Meer DM, Fathers LM, Valentijn AR, Oostendorp J, Fleuren GJ, Melief CJ, Kenter GG, van der Burg SH (2013). HPV16 synthetic long peptide (HPV16-SLP) vaccination therapy of patients with advanced or recurrent HPV16-induced gynecological carcinoma, a phase II trial. J TransI Med 11:88.

158. Stevanovic S, Draper LM, Langhan MM, Campbell TE, Kwong ML, Wunderlich JR, Dudley ME, Yang JC, Sherry RM, Kammula US, Restifo NP, Rosenberg SA, Hinrichs CS (2015). Complete regression of metastatic cervical cancer after treatment with human papillomavirus-targeted tumor-infiltrating $T$ cells. J Clin Oncol 33(14):1543-50.

159. Welters MJ, Piersma SJ, van der Burg SH (2008). T-regulatory cells in tumour-specific vaccination strategies. Expert Opin Biol Ther 8(9):1365-79.

160. Pombo C, Wherry EJ, Gostick E, Price DA, Betts MR (2015). Elevated Expression of CD160 and 2B4 Defines a Cytolytic HIV-Specific CD8+ T-Cell Population in Elite Controllers. J Infect Dis 212(9):1376-86.
161. Shin H, Iwasaki A (2012). A vaccine strategy that protects against genital herpes by establishing local memory $T$ cells. Nature 491(7424):463-7.

162. Ojesina Al, Lichtenstein L, Freeman SS, Pedamallu CS, ImazRosshandler I, Pugh TJ, Cherniack AD, Ambrogio L, Cibulskis K, Bertelsen B, Romero-Cordoba S, Trevino V, Vazquez-Santillan K, Guadarrama AS, Wright AA, Rosenberg MW, Duke F, Kaplan B, Wang R, Nickerson E, Walline HM, Lawrence MS, Stewart C, Carter SL, McKenna A, Rodriguez-Sanchez IP, Espinosa-Castilla M, Woie MK, Bjorge L, Wik E et al (2014). Landscape of genomic alterations in cervical carcinomas. Nature 506(7488):371-5.

163. Hansen SG, Piatak M, Jr., Ventura AB, Hughes CM, Gilbride RM, Ford JC, Oswald K, Shoemaker R, Li Y, Lewis MS, Gilliam AN, Xu G, Whizin N, Burwitz BJ, Planer SL, Turner JM, Legasse AW, Axthelm MK, Nelson JA, Fruh K, Sacha JB, Estes JD, Keele BF, Edlefsen PT, Lifson JD, Picker $\amalg$ (2013). Immune clearance of highly pathogenic SIV infection. Nature 502(7469):100-4.

164. Linnemann C, van Buuren MM, Bies L, Verdegaal EM, Schotte R, Calis JJ, Behjati S, Velds A, Hilkmann H, Atmioui DE, Visser M, Stratton MR, Haanen JB, Spits H, van der Burg SH, Schumacher TN (2015). Highthroughput epitope discovery reveals frequent recognition of neoantigens by CD4+ T cells in human melanoma. Nat Med 21(1):81-5.

165. van Buuren MM, Calis JJ, Schumacher TN (2014). High sensitivity of cancer exome-based CD8 $\mathrm{T}$ cell neo-antigen identification. Oncoimmunology 3:e28836.

166. Brown SD, Warren RL, Gibb EA, Martin SD, Spinelli JJ, Nelson BH, Holt RA (2014). Neo-antigens predicted by tumor genome metaanalysis correlate with increased patient survival. Genome Res 24(5):743-50.

167. Yewdell JW, Anton LC, Bennink JR (1996). Defective ribosomal products (DRiPs): a major source of antigenic peptides for $\mathrm{MHC}$ class I molecules? J Immunol 157(5):1823-6.

168. Yewdell JW, Nicchitta CV (2006). The DRiP hypothesis decennial: support, controversy, refinement and extension. Trends Immunol 27(8):368-73.

169. Lorenz FK, Wilde S, Voigt K, Kieback E, Mosetter B, Schendel DJ, Uckert W (2015). Codon optimization of the human papillomavirus E7 oncogene induces a CD8+ T cell response to a cryptic epitope not harbored by wild-type E7. PLoS One 10(3):e0121633.

170. Biryukov J, Meyers C (2015). Papillomavirus Infectious Pathways: A Comparison of Systems. Viruses 7(8):4303-25.

171. Raff AB, Woodham AW, Raff LM, Skeate JG, Yan L, Da Silva DM, Schelhaas $M$, Kast WM (2013). The evolving field of human papillomavirus receptor research: a review of binding and entry. J Virol 87(11):6062-72.

172. Schelhaas M, Shah B, Holzer M, Blattmann P, Kuhling L, Day PM, Schiller JT, Helenius A (2012). Entry of human papillomavirus type 16 by actin-dependent, clathrin- and lipid raft-independent endocytosis. PLoS Pathog 8(4):e1002657.

173. Buck CB, Pastrana DV, Lowy DR, Schiller JT (2005). Generation of HPV pseudovirions using transfection and their use in neutralization assays. Methods Mol Med 119:445-62.

174. Culp TD, Budgeon LR, Christensen ND (2006). Human papillomaviruses bind a basal extracellular matrix component secreted by keratinocytes which is distinct from a membraneassociated receptor. Virology 347(1):147-59.

175. Buck CB, Thompson CD, Roberts JN, Muller M, Lowy DR, Schiller JT (2006). Carrageenan is a potent inhibitor of papillomavirus infection. PLoS Pathog 2(7):e69. 
176. Selinka HC, Giroglou T, Sapp M (2002). Analysis of the infectious entry pathway of human papillomavirus type 33 pseudovirions. Virology 299(2):279-87.

177. Woodham AW, Da Silva DM, Skeate JG, Raff AB, Ambroso MR, Brand HE, Isas JM, Langen R, Kast WM (2012). The S100A10 subunit of the annexin A2 heterotetramer facilitates L2-mediated human papillomavirus infection. PLoS One 7(8):e43519.

178. Bienkowska-Haba M, Patel HD, Sapp M (2009). Target cell cyclophilins facilitate human papillomavirus type 16 infection. PLoS Pathog 5(7):e1000524.

179. Scheffer KD, Berditchevski F, Florin L (2014). The tetraspanin CD151 in papillomavirus infection. Viruses 6(2):893-908.

180. Kines RC, Thompson CD, Lowy DR, Schiller JT, Day PM (2009). The initial steps leading to papillomavirus infection occur on the basement membrane prior to cell surface binding. Proc Natl Acad Sci USA 106(48):20458-63.
181. Day PM, Schelhaas M (2014). Concepts of papillomavirus entry into host cells. Curr Opin Virol 4:24-31.

182. Cruz L, Meyers C (2013). Differential dependence on host cell glycosaminoglycans for infection of epithelial cells by high-risk HPV types. PLoS One 8(7):e68379.

183. Patterson NA, Smith JL, Ozbun MA (2005). Human papillomavirus type $31 \mathrm{~b}$ infection of human keratinocytes does not require heparan sulfate. J Virol 79(11):6838-47.

184. Culp TD, Cladel NM, Balogh KK, Budgeon LR, Mejia AF Christensen ND (2006). Papillomavirus particles assembled in 293TT cells are infectious in vivo. J Virol 80(22):11381-4. 